\title{
Enzyme activity and biochemical changes during production of Lentinula edodes (Berk.) Pegler
}

\author{
Maiara Andrade de Carvalho SOUSA ${ }^{1}$, Lívia Martinez Abreu Soares COSTA ${ }^{1}$, Thiago Souza PEREIRA ${ }^{1}$, \\ Diego Cunha ZIED², Danny Lee RINKER², Eustáquio Souza DIAS ${ }^{1 *}$
}

\begin{abstract}
Shiitake is an important edible and medicinal mushroom cultivated worldwide. Its cultivation involves a complex process of browning that precedes the primordia initiation. The present work through the evaluation of enzymes, lectin and $\beta$-glucan during the cultivation cycle of Lentinula edodes, the degradation of cellulose, hemicellulose and lignin, attempted to correlate these with mushroom yield. Strains UFLA-LE1, UFLA-LE2 and UFLA-LE6 consumed significantly more hemicelluloses than the other three strains with strain LE5 consuming significantly the most lignin of all six strains. Strains UFLA-LE4 and UFLA-LE6 were significantly the most productive. The laccase activity increased continuously until the end of the cultivation for all strains. Manganese peroxidase activities, except for UFLA-LE3, remained relatively stable. On the other hand, lignin peroxidase was the main lignin-modifying enzyme with much higher activity compared to laccase and manganese peroxidase. Tyrosinase activity was stable at an elevated level during the cultivation cycle, dramatically reaching the highest activity at the end of the cultivation period. The amounts of lectin and $\beta$-glucan varied greatly depending on the strain and the time of cultivation. Despite the many differences between strains in all evaluated parameters no direct association to the browning process was observed.
\end{abstract}

Keywords: shiitake; lectin; enzymes; $\beta$-glucan.

Practical Aplication: The parameters studied are potentially involved in the mushroom frutification.

\section{Introduction}

The cultivation of shiitake (Lentinula edodes Berk. Pegler), in addition to Asian and North American countries, has attracted the interest of developing countries such as Brazil (Dias, 2010). Shiitake is one of the most important edible mushrooms in the world from the standpoint of production, and it is one the most popular fungus cultivated (Chang \& Wasser, 2017). It is not only valued as a highly desirable culinary mushroom for its pleasant taste but also for its nutritional and therapeutic properties (Menolli \& Paccola-Meirelles, 2010; Sousa et al., 2016; Royse et al., 2017).

Shiitake mushrooms have been traditionally cultivated on logs of various species of trees such as oak and eucalyptus. However, the axenic cultivation on synthetic substrates, based upon different agricultural residues, has been gaining popularity in commercial production because the time to harvest is faster and productivity is much higher (Philippoussis et al., 2007; Zied et al., 2016).

Four phases are recognized during the shiitake growing cycle: vegetative mycelial growth, browning process, primordium formation and fruiting body development (Tang et al., 2013). The growth phases are affected by the proportion of lignin and cellulose as well as by the nitrogen content of the substrate. As a white rot fungus, L. edodes secretes hydrolytic (cellulases and hemicellulases) and oxidative enzymes (lignin-modifying enzymes - LMEs) to degrade lignocellulose (Carvalho et al., 2016; Chen et al., 2016).

Mycelial aggregation is required for the assimilation of the substrate and for the development and growth of the colony, and the fungus needs to mobilize sugars and transport them. During this phase, a key role is played by lectins, which are involved in carbohydrate, intercellular bridges and signal transduction in biological systems (Konska, 2006; Nikitina et al., 2017). In addition, during the mycelial growth and cell cycle, the cell wall structure of fungi is constantly changing. The morphological alterations involving synthesis, re-orientation and lysis of the cell wall structure are an essential process in fungi. The cell wall consists of multiple layers of polysaccharide, glycoproteins and proteins with cross links. Polysaccharides are comprised of $\beta$-glucans (chiefly $\beta$-1,3-glucan and $\beta$-1, 6 -glucan), chitin, chitosan, mannan and $\alpha$-glucans (Aimanianda et al., 2010; Nikitina et al., 2017).

The formation of the brown mycelial film precedes the appearance of the fruiting bodies (Tang et al. 2013) and has been described as an essential step in the morphogenesis for shiitake (Chum et al., 2008; Tsivileva et al., 2005). However, the molecular and biochemical mechanisms of its formation are still unclear (Tang et al., 2013). Some studies point out that protein lectin is likely responsible for the brown mycelial film, but the 
published studies have been conducted only in synthetic culture media, not under the real cultivation conditions of the brown film formation (Tsivileva et al., 2005; Vetchinkina et al., 2008). Therefore, it is important to evaluate the activity of potential candidate proteins using different strains with diverse levels of mushroom yield in a standard cultivation system.

This work was carried out with the following four objectives: to evaluate the production of ligninase, tyrosinase and lectin during the four growth phases of Lentinula edodes strains in order to better understand the macromolecules possibly involved in the development of the brown mycelial film, to determine the $\beta$-glucan content in each phase that accompanies the changes in the cell wall during the different growth phases, to verify the utilization of lignin, cellulose, hemicelluloses, and to evaluate the mushroom yield by each strain.

\section{Materials and methods}

\subsection{Fungus and culture conditions}

Six strains of Lentinula edodes (UFLA-LE1, UFLA-LE2, UFLA-LE3, UFLA-LE4, UFLA-LE5 and UFLA-LE6) as described by Zied et al. (2016) were utilized. The stock cultures were maintained on malt agar medium $\left(15.0 \mathrm{~g} \mathrm{~L}^{-1}\right.$ of glucose; $15.0 \mathrm{~g} \mathrm{~L}^{-1}$ of malt extract; $15.0 \mathrm{~g} \mathrm{~L}^{-1}$ of agar) and incubated at $25^{\circ} \mathrm{C}$.

\subsection{Spawn preparation}

The spawn was prepared using Eucaliptus sawdust (9 kg), wheat meal (1 kg), gypsum (200 g) and agricultural lime (200 g). Moisture was adjusted to $60 \%$ and $170 \mathrm{~g}$ of that substrate were distributed into glass flasks. The substrate was autoclaved twice: two hours at $121^{\circ} \mathrm{C}$ and 24 hours later for two hours. After inoculation of the strains, incubation was conducted at room temperature $\left(25 \pm 2^{\circ} \mathrm{C}\right)$ until the substrate was completely colonized by the fungus in 20 days.

\subsection{Axenic cultivation}

The substrate for the axenic cultivation of $L$. edodes was prepared as described by Zied et al. (2016).

\subsection{Fruiting induction}

Ninety days after spawning, fruitification was initiated. The brown film was not completely formed but some treatments began to show primordium formation. The plastic was removed from the substrate and each block was placed inside the mushroom production facility and maintained at a temperature of $18 \pm 2{ }^{\circ} \mathrm{C}$ and a relative humidity of $89 \pm 5 \%$. Under these conditions primordia formation was followed by the first flush of mushrooms. The blocks were kept under these conditions for an additional 36 days, totaling 126 days after spawning (DAS). After 126 DAS, the browning process was considered complete and the blocks were soaked in water $\left(14 \pm 2{ }^{\circ} \mathrm{C}\right)$ for 12 hours to restore the moisture and induce the second flush of mushrooms. The blocks were returned to the mushroom facility under the same environmental conditions for the second flush. After the second flush was complete (159 DAS), the blocks were again soaked. Third flush mushroom harvest was completed 189 DAS.

\subsection{Mushroom productivity}

The mushrooms were harvested when they reached the maximum size and with their carpophore edges still curving downwards. The base of the stipe was cut before weighing. The mushrooms from each block were weighed for the determination of productivity (\%), according to following Equation 1:

$P(\%)=\frac{\text { Mass of the fresh mushrooms }}{\text { Mass of the wet substrate }} \times 100$

\subsection{Sample collection}

Substrate samples were analysed from each strain of $L$. edodes at four times during the vegetative and production period. Four samples were obtained from each strain of $L$. edodes. At each sampling time, three blocks were sacrificed from each strain. Each block was completely broken up and mixed separately before the sample was taken. The first sample was obtained at $60 \mathrm{DAS}$, when all blocks of all strains were totally colonized. The second sample was obtained at $90 \mathrm{DAS}$, at fruiting induction. The third sample was obtained at $126 \mathrm{DAS}$, at the end of the first flush. The fourth and last sample was obtained at 159 DAS, at the end of the second flush. The content of lectin, $\beta$-glucan, tyrosinase and ligninase activity were determined for each sample collected.

\subsection{Preparation of the crude protein extract}

The crude extract for the lectin analyses were prepared according to Vetchinkina et al. (2008). This solution was analyzed in the hemagglutination assays. For analyses of tyrosinase and ligninases, the crude extract was prepared according to Luz et al. (2012). All enzyme and hemagglutination assays were conducted in triplicate.

\subsection{Enzyme assays}

Lacase (EC 1.10.3.2)

The laccase activity was determined by indirect spectrophotometric (Association of Official Analytical Chemists, 2000) method utilizing 2,2-azino-bis ethylbentiazoline (ABTS), in reaction mixture of $1 \mathrm{~mL}$ containing $0.3 \mathrm{~mL}$ of $0.1 \mathrm{~mol} \mathrm{~L}^{-1}$ sodium acetate buffer (pH 5.0), $0.1 \mathrm{~mL}$ of ABTS $1 \mathrm{mmol} \mathrm{L}^{-1}$ (in water) and $0.6 \mathrm{~mL}$ of the enzyme source. A unit of enzyme activity was defined as the amount of enzyme capable of oxidizing $1 \mu \mathrm{mol}$ of ABST per minute $\left(\varepsilon_{420}=3.6 \times 10^{4} \mathrm{~mol}^{-1} \mathrm{~L} \mathrm{~cm}^{-1}\right)$, per kg.

\section{Manganese peroxidase (EC 1.11.1.13)}

The activity of manganese peroxidase was measured as described by Kuwahara et al. (1984), utilizing phenol red $\left(1 \mathrm{~g} \mathrm{~L}^{-1}\right)$ as a substrate $\left(\varepsilon=4.460 \mathrm{~mol}^{-1} \mathrm{~L} \mathrm{~cm}^{-1}\right)$. Absorbance was measured at $610 \mathrm{~nm}$. A unit of enzyme activity was defined as the amount of enzyme capable of oxidizing $1 \mu \mathrm{mol}$ of phenol red per minute per $\mathrm{kg}$.

\section{Lignin peroxidase (EC 1.11.1.14)}

The lignin peroxidase activity was determined by the monitoring of absorbance at $310 \mathrm{~nm}$ of the formation of veratraldehyde $\left(\varepsilon=9,300 \mathrm{~mol}^{-1} \mathrm{~L} \mathrm{~cm}^{-1}\right)$, by means of the oxidation of veratryl 
alcohol (Tien \& Kirk, 1984). A unit of enzyme activity was defined as the amount of enzyme capable of oxidizing $1 \mu \mathrm{mol}$ of veratryl acid per minute per $\mathrm{kg}$.

\section{Tyrosinase (E.C.1.14.18.1)}

Determined by the oxidation rate of L-di-hydroxiphenylalanine (L-DOPA) $2 \mathrm{mmol} \mathrm{L}^{-1}$ in $50 \mathrm{mmol} \mathrm{L}^{-1}$ Tris-HCl buffer ( $\mathrm{pH} 7.5$ ) at $37^{\circ} \mathrm{C}$ for 10 minutes. The oxidation of L-DOPA was measured according to Pomerantz \& Murthy (1974) by the increase of absorbance at $475 \mathrm{~nm}\left(\varepsilon_{475} 3700 \mathrm{M}^{-1} \mathrm{~cm}^{-1}\right)$. A unit of enzyme activity was defined as the amount of enzyme capable of oxidizing $1 \mu \mathrm{mol}$ of L-DOPA per minute per $\mathrm{kg}$.

\section{Hemagglutination assay}

Hemagglutination was carried out to verify the lectin activity. The assay was conducted by a serial dilution of the sample, using the kit TOXO-HAI Gold Analisa (Belo Horizonte-MG-Brazil), which contains the diluent and a suspension of $2 \%$ bird erythrocytes. The activity was expressed at $\mathrm{UH} 50 \mu \mathrm{L}^{-1}$ (Tsivileva et al., 2001).

\section{$2.9 \beta$-glucan extraction and quantification}

The extraction and quantification of $\beta$-glucan were conducted utilizing the $\beta$-Glucan kit (Yeast \& Mushroom) of Megazyme (Megazyme International Ireland, Ireland).

\subsection{Determination of lignin, cellulose and hemicellulose}

The content of lignin, cellulose and hemicellulose of the mushroom substrate was quantified before spawning (0 DAS) and at the end of the third flush (189 DAS) to evaluate their utilization by each strain. The analysis of the dry matter content (DM) was carried out according to recommendations of the Association of Official Analytical Chemists (2000). The contents of neutral detergent fiber (NDF) and acid detergent fiber (ADF), hemicellulose (HEM), cellulose (CEL) and lignin (LIG) were determined according to Silva (1998).

\section{Statistics}

The experiment was arranged in a completely randomized design (CRD). At each sample collection time, three blocks of each strain were removed for the quantification of lectin, enzymes and $\beta$-glucan. The analyses for the determination of lignin, cellulose and hemicellulose were conducted with three repetitions, while six repetitions were utilized to evaluate the yield. The statistical analyses were performed using SISVAR software and the means separated according to the Scott-Knott test at $5 \%$ probability (Ferreira, 2008).

Pearson product-moment correlations were run between the average of the total glucan, $\alpha$-glucan, $\beta$-glucan, laccase, manganese peroxidase, lignin peroxidase, tyrosinase, lectin and mushroom yield for sampling times 126 DAS (end of first flush) and 159 DAS (end of second flush) and similarly correlations were run between final yield and the measurements of cellulose, hemicellulose and lignin at crop termination (189 DAS) using SIGMA STAT 2.0 software (San Jose, California).

\section{Results and discussion}

\subsection{Lignin, cellulose and hemicellulose}

The initial chemical composition of the mushroom substrate utilized for L. edodes cultivation was cellulose (40.3\%), followed by hemicellulose (20.7\%) and lignin (20.8\%) (Table 1). All the strains significantly utilized cellulose, hemicellulose and lignin, although differently (Table 1). Consumption (difference between control and measured value) of cellulose was significantly the highest for LE1 and 3 and the lowest for LE4 and 6. Degradation of hemicellulose was statistically identical for strains LE1, 2 and 6, and for strains LE3, 4 and 5, while lignin was most significantly degraded by strain LE5.

Correlation analyses indicated that the only significant relationship between crop production and the disappearance of cellulose, hemicellulose or lignin at crop termination was cellulose $(\mathrm{r}=-0.93 ; \mathrm{p}=0.0076)$ (data not shown), an inverse relationship where there was higher productivity with lower cellulose consumption.

Mushrooms have the capability to degrade lignin using laccase, lignin peroxidase and/or manganese peroxidase. Substrate degradation is affected by the amount of secreted enzymes and, as result, mushroom production (Xu et al., 2013). In this work, we observed significant differences in lignin consumption between strains, but there was not significant correlation between lignin and hemicellulose consumption and mushroom yield. In fact, there was a significantly negative correlation between yield and cellulose utilization.

Philippoussis et al. (2003) tested three formulations of substrates containing increasing concentrations of hemicellulose for $L$. edodes cultivation and found faster growth and early fruiting in the two substrates with highest content of hemicellulose. Zied et al. (2016) reported higher mushroom yield when the sawdust-based substrate was supplemented with diverse kinds of bran or meal. Those supplements likely enriched the substrate with hemicellulose and soluble sugars, besides nitrogen, vitamins, amino acids, etc. We used the same richer substrate reported by Zied et al. (2016).

Table 1. Cellulose, hemicellulose and lignin content of the mushroom substrate after cultivation by six strains of Lentinula edodes. Control: substrate before cultivation.

\begin{tabular}{lccc}
\hline Strain & $\begin{array}{c}\text { Cellulose } \\
(\%)\end{array}$ & $\begin{array}{c}\text { Hemicellulose } \\
(\%)\end{array}$ & $\begin{array}{c}\text { Lignin } \\
(\%)\end{array}$ \\
\hline Control & $40.3 \pm 0.30^{\mathrm{a}}$ & $20.7 \pm 0.40^{\mathrm{a}}$ & $20.8 \pm 2.30^{\mathrm{a}}$ \\
UFLA-LE1 & $29.5 \pm 0.17^{\mathrm{f}}$ & $13.8 \pm 0.80^{\mathrm{c}}$ & $15.6 \pm 0.20^{\mathrm{d}}$ \\
UFLA-LE2 & $33.7 \pm 0.11^{\mathrm{d}}$ & $14.7 \pm 0.70^{\mathrm{c}}$ & $15.8 \pm 0.70^{\mathrm{d}}$ \\
UFLA-LE3 & $29.3 \pm 0.43^{\mathrm{f}}$ & $17.2 \pm 0.20^{\mathrm{b}}$ & $16.8 \pm 0.40^{\mathrm{c}}$ \\
UFLA-LE4 & $35.4 \pm 0.10^{\mathrm{b}}$ & $15.7 \pm 0.20^{\mathrm{b}}$ & $17.6 \pm 0.45^{\mathrm{b}}$ \\
UFLA-LE5 & $31.4 \pm 0.51^{\mathrm{e}}$ & $16.5 \pm 0.50^{\mathrm{b}}$ & $14.3 \pm 0.41^{\mathrm{e}}$ \\
UFLA-LE6 & $34.7 \pm 0.30^{\mathrm{c}}$ & $14.4 \pm 0.47^{\mathrm{c}}$ & $16.4 \pm 0.32^{\mathrm{c}}$ \\
\hline
\end{tabular}

Means followed by the same letters in the same column do not differ significantly from one another according the Scott-Knott test at $5 \%$ level. 


\subsection{Mushroom production}

Strains LE4 and LE6 were the most productive, 26.9 and 26.2\% respectively, followed by LE2, at $13.1 \%$. The remaining strains had significantly lesser productivity (Table 2). Strains LE4 and LE6 were superior to the other strains by producing more than $60 \%$ of the total yield in the first flush (65.8\% and $61.8 \%$, respectively). In the following flushes, productivity varied between strains with substantially smaller ranges than in the first flush. Pearson product-moment correlations among mushroom productivity, cellulose, hemicellulose and lignin showed only a significantly negative correlation $(\mathrm{r}=-0.9279, \mathrm{p}=0.0076)$ (data not shown) between productivity and cellulose disappearance. Although strains LE1 and 3 consumed more cellulose, their productivity was lower than strains LE4 and 6 which digested less cellulose.

\subsection{Enzyme activity}

Laccase activity increased throughout the production period especially from the fruiting induction at 90 DAS (Figure 1). When compared to the activity at 90 DAS, the laccase activity was significantly higher for all strains at 126 DAS. At the last evaluation at the end of second flush (159 DAS), strains LE3, 4 and 6 continued to increase in laccase activity. Strain LE4 had the highest laccase activity at 159 DAS (22.45 U kg-1), followed by LE6 $\left(20.18 \mathrm{U} \mathrm{kg}^{-1}\right)$.

The formation of the brown mycelial film is extremely important to the mushroom production, since the brown film formation precedes the primordia initiation. Several factors are suggested to be involved in the formation of the pigmented mycelial film, among them, the production of laccase and lectin (Chen et al., 2004; Vetchinkina et al., 2015). In Agaricus bisporus and $L$. edodes, the laccase activity is reported to be higher immediately before the formation of the fruiting bodies, declining rapidly after formation of primordia (Kües \& Liu, 2000). However, in the present work we observed an increase in laccase activity after the first flush instead of a decline.

The laccase activity in L. edodes is associated with pigment formation during development of fruiting bodies and other fungal structures. The production of fruiting bodies may involve this enzyme activity during the synthesis of extracellular pigments related to the oxidative polymerization of cell wall components for the strengthening of cell-cell adhesion (Singh Arora \& Kumar Sharma, 2010).

The browning process is accelerated by oxygen and laccase activity (Tang et al., 2013). As a result of the formation of phenolic

Table 2. Total and per flush productivity of six strains of Lentinula edodes.

\begin{tabular}{ccccc}
\hline \multirow{2}{*}{ Strain } & \multicolumn{4}{c}{ Productivity (\%) } \\
\cline { 2 - 5 } & First flush & Second flush & Third flush & Total \\
\hline UFLA-LE1 & 2.0 & 1.4 & 2.8 & $6.20^{\mathrm{b}}$ \\
UFLA-LE2 & 5.7 & 3.1 & 4.3 & $13.1^{\mathrm{b}}$ \\
UFLA-LE3 & 1.2 & 0.0 & 1.4 & $2.60^{\mathrm{b}}$ \\
UFLA-LE4 & 17.7 & 6.3 & 2.9 & $26.9^{\mathrm{a}}$ \\
UFLA-LE5 & 0.0 & 0.0 & 5.5 & $5.50^{\mathrm{b}}$ \\
UFLA-LE6 & 16.2 & 3.0 & 7.0 & $26.2^{\mathrm{a}}$ \\
\hline
\end{tabular}

Means followed by the same letters in the same column do not differ significantly from one another according to the Scott-Knott test at $5 \%$ level. compounds, water droplets are produced because oxygen is reduced to water (Singh Arora \& Kumar Sharma, 2010). This explains why large quantities of water are observed in the plastic bag during the browning process, necessitating that the water be drained. Besides the browning process, other studies have reported the importance of laccases to the fruiting body development and the pigment production in edible mushrooms (Chen et al., 2004). The higher laccase activity during the period of mushroom production compared to the period of substrate colonization in this present work corroborates the greater importance of laccase for mushroom production than lignin degradation.

The activity of manganese peroxidase behaved in a somewhat opposite manner compared to laccase production (Figure 2). There was a general decline in activity over the four sampling periods with the exception of strain LE3 which showed an increased activity at $159 \mathrm{DAS}\left(33.56 \mathrm{U} \mathrm{kg}^{-1}\right)$.

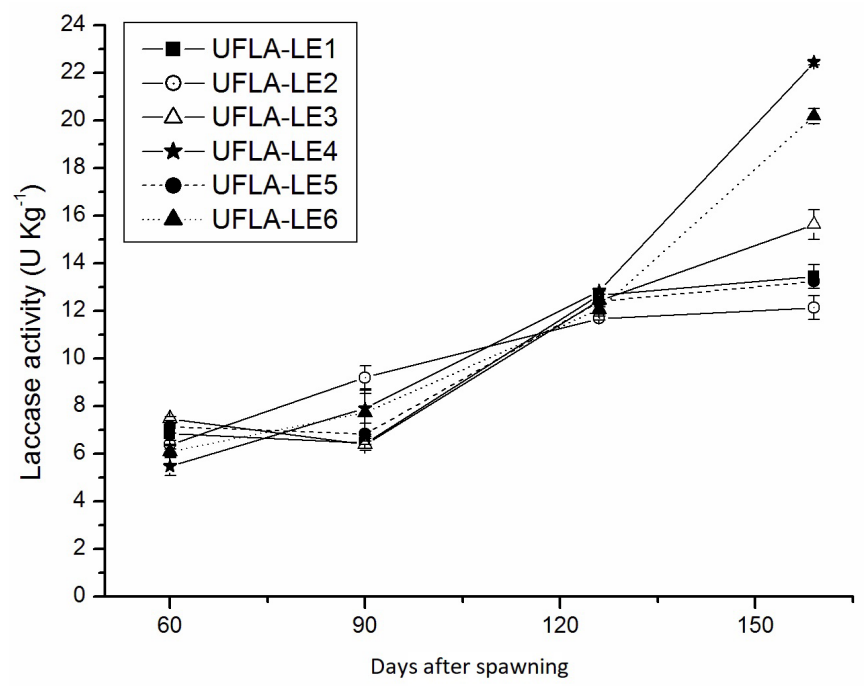

Figure 1. Laccase activity (U: unit of enzyme activity) of the mushroom substrate for six strains of Lentinula edodes.

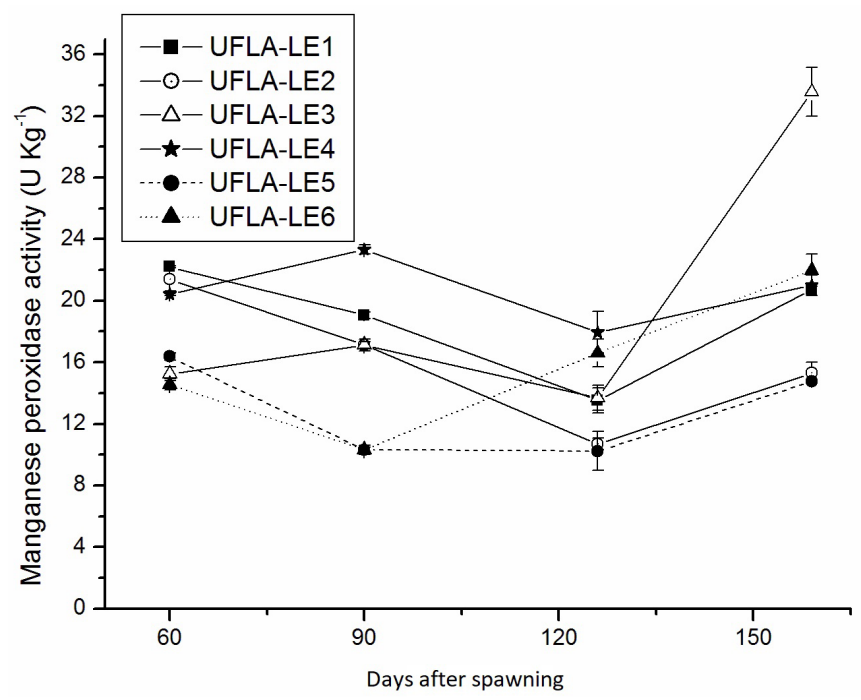

Figure 2. Manganese peroxidase activity (U: unit of enzyme activity) of the mushroom substrate for six strains L. edodes. 
Activity of lignin peroxidase steadily increased until the second flush (126 DAS) for all strains (Figure 3), except for strain LE1 which did not show an increase in activity until 126 DAS. On the other hand, this strain showed the highest initial activity $\left(438.10 \mathrm{U} \mathrm{kg}^{-1}\right)$. Strain LE5 showed the lesser initial activity $\left(172.79 \mathrm{U} \mathrm{kg}^{-1}\right)$ at $60 \mathrm{DAS}$ but it had its maximum activity at 126 DAS (801.28 $\left.\mathrm{U} \mathrm{kg}^{-1}\right)$. Activity at the end of second flush, prior to third flush, was variable with some strains increasing in activity from the previous sample and others decreasing.

The initial manganese peroxidase activity was higher than the initial laccase activity and it remained relatively stable during the entire cultivation cycle. In addition, the activities of laccase and manganese peroxidase were much lower compared to the activity of lignin peroxidase for all the strains in all periods of cultivation. The capacity of degrading lignin is reported to depend on the production of laccase, manganese peroxidase and lignin peroxidase.

Manganese and lignin peroxidases are reported as real ligninases, due to their high redox potential that is directly related to the efficiency of lignin degradation (Gold et al., 2000). According to Martínez (2002), when the activity of lignin peroxidase is high, the activities of laccase and manganese peroxidase are lower. We observed that the activities of laccase and manganese peroxidase of our six strains were much less than the activity of lignin peroxidase. This substantially higher activity of lignin peroxidase is an evidence that this enzyme plays the main function in lignin degradation for L. edodes.

Tyrosinase activity was substantially higher compared to the other enzymes (highest initial activity of $314.19 \mathrm{U} \mathrm{kg}^{-1}$ for LE4 and highest final activity of $1510.27 \mathrm{U} \mathrm{kg}^{-1}$ for LE5. However, there were minor changes in activity not until 159 DAS (Figure 4) at which time all strains were measured with substantial increases from the previous measurement. During the period between 60 and 90 DAS, the activity slightly increased for two strains (LE3 and LE4) and slightly decreased for two strains (LE1 and LE6) while for the two remaining strains (LE2 and LE5) the activity did not vary. At the second flush (126 DAS), the strains returned to the initial values, except for strain LE6 which decreased.

Tyrosinase activity was much higher compared to laccase and manganese peroxidase, and increased sharply for all strains at 159 DAS. In contrast to manganese peroxidase and lignin peroxidase, the low redox potential of tyrosinase suggests that this enzyme does not take part in degradation processes, but in the pigment production during the browning process. Its high activity from the beginning of substrate colonization is evidence for its importance thorough out all the cultivation cycles. On the other hand, this sudden increase by 159 DAS may suggest a more intense production of melanin at the end of cultivation as the external layer of the substrate becomes more and more leathery. Strain LE5 showed the highest tyrosinase activity at 159 DAS, followed by LE4.

\subsection{Lectin activity}

During the period between 60 and 90 DAS, there was no change in lectin production among the four strains (Figure 5).
Strain LE6 showed the highest initial lectin production (8 $\mathrm{UH}_{50} \mu^{-1}$ ) but dropped to $1 \mathrm{UH} 50 \mu \mathrm{l}^{-1}$ at 90 DAS. LE1 had no detectable activity of lectin production for both 60 and 90 DAS. However, at the next two sampling periods there was a marked increase in its lectin activity. The greatest activity of lectin (32 $\mathrm{UH} 50 \mu \mathrm{L}^{-1}$ ) was detected for the strains LE4 and LE3 at 126 and 159 DAS, respectively. For all strains, the lectin activity increased from the period of substrate colonization and browning though to the last sampling prior to third flush. However, within the overall pattern of increased lectin production strain LE6 decreased initially and later steadily increased and strain LE4 rose to maximum height at 126 DAS to later decrease to about half of that value at 159 DAS.

The activities of laccase and lectin at 126 and 159 DAS, were higher than 60 or 90 DAS for all strains. According to Vetchinkina et al. (2008), lectins of $L$. edodes stabilize the activity

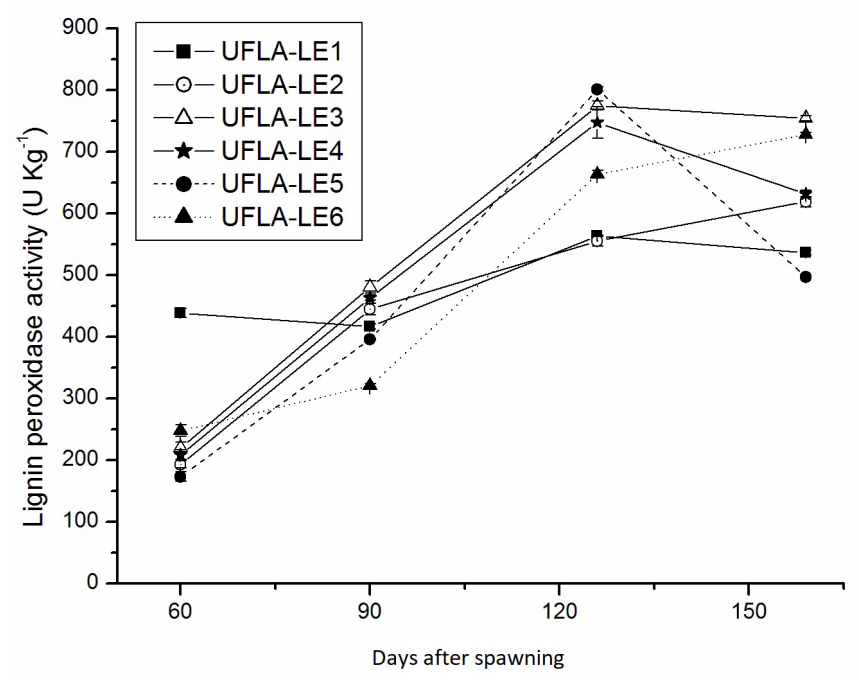

Figure 3. Lignin peroxidase activity (U: unit of enzyme activity) of the mushroom substrate for six strains of L. edodes.

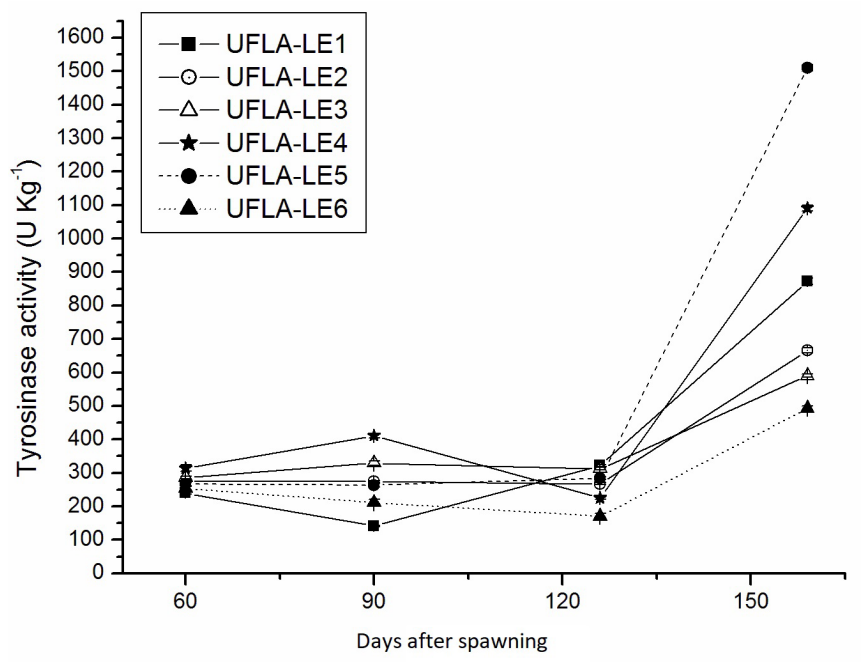

Figure 4. Tyrosinase activity (U: unit of enzyme activity) of the mushroom substrate for six strains of Lentinula edodes. 
of laccases. In our work, we observed the increase of lectin and laccase in a similar manner, which may occur as a function of the positive effect of lectin on the laccase activity, as observed by Vetchinkina et al. (2008).

\subsection{Content of $\beta$-glucan}

Strain LE6 demonstrated the highest content of $\beta$-glucan at 60 and 90 DAS but decreased thereafter (Figure 6).

The other strains showed a tendency to increase in $\beta$-glucan content through 126 DAS, when the highest values were obtained. Together with LE6, the strain LE4 reached the highest $\beta$-glucan content at 90 DAS. Strain LE6 showed the most divergent behavior of $\beta$-glucan content compared to the other strains, reaching the highest values at 60 and 90 DAS but decreasing after that. Strain LE4 showed an opposite behavior, with a low initial $\beta$-glucan content but increasing to the same value as LE6

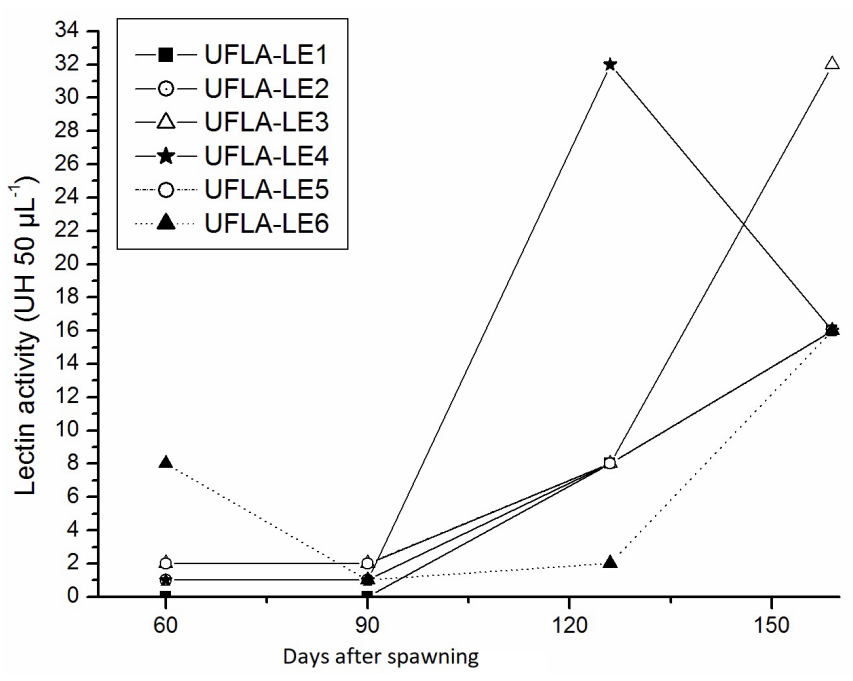

Figure 5. Lectin activity (UH: hemagglutinating units.) of the mushroom substrate for six strains of $L$. edodes.

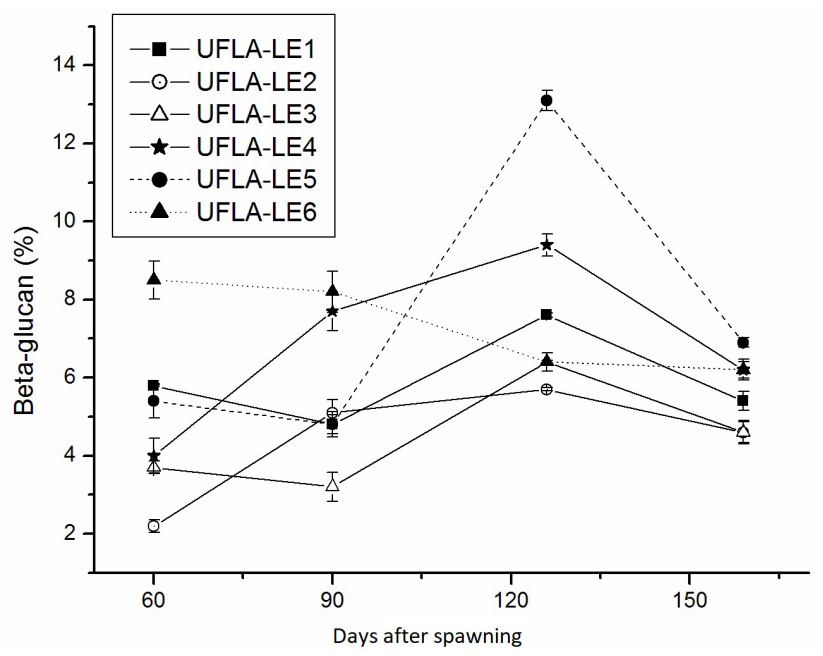

Figure 6. $\beta$-glucan (\%) content of the mushroom substrate for six strains of L. edodes. at 90 DAS. The first fruiting induction happened exactly at this time. Even with divergent $\beta$-glucan behavior (LE4 increasing the $\beta$-glucan content and LE4 decreasing) both strains produced the same content of $\beta$-glucan at the start of mushroom production. This might be considered as an evidence for the importance of $\beta$-glucan to the fruiting induction but it is not confirmed by the result obtained from the strain LE2. According to correlation analysis, a positive correlation was observed between manganese peroxidase and cellulose content after mushroom cultivation and productivity, and a negative correlation between tyrosinase and productivity. The higher cellulose content means a lower degradation by cellulose activity, therefore, a higher productivity was correlated to a lower cellulose degradation and such behavior was not expected because it is common to correlate a higher cellulose utilization with higher mushroom yield.

\section{Conclusions}

In conclusion, considering all parameters evaluated in this work with the use of different strains with different agronomic performance, we may clearly state that fruiting induction and mushroom production is more complex than the factors that we have measured. Although all strains colonized the substrate well, production was quite varied. Therefore, more detailed studies are necessary to establish other factors that not only induce the brown film formation but other metabolic processes related to substrate degradation, biosynthesis reactions and mushroom production.

\section{Acknowledgements}

The FAPEMIG (Fundação de Amparo à Pesquisa de Estado de Minas Gerais), CAPES (Coordenação de Aperfeiçoamento de Pessoal de Nível Superior) and the $\mathrm{CNPq}$ (Conselho Nacional de Desenvolvimento Científico e Tecnológico) are acknowledged for financial support.

\section{References}

Aimanianda, V., Bayry, J., Bozza, S., Kniemeyer, O., Perruccio, K., Elluru, S. R., Clavaud, C., Paris, S., Brakhage, A. A., Kaveri, S. V., Romani, L., \& Latgé, J. P. (2010). Surface hydrophobin prevents immune recognition of airborne fungal spores. Nature, 460(7259), 1117-1121. http://dx.doi.org/10.1038/nature08264. PMid:19713928.

Association of Official Analytical Chemists - AOAC. (2000). Official methods of the Association of Official Analytical Chemists (17th ed., pp. 190). Gaithersburg: AOAC.

Carvalho, M. A., Costa, L. M. A. S., Santos, D. M. S. E., Dias, D. R., Zied, D. C., \& Dias, E. S. (2016). Ligninase and cellulase activity of Lentinula edodes (Berk.) Pegler strains in different culture media. Journal of Pure \& Applied Microbiology, 10, 1683-1691.

Chang, S., \& Wasser, S. (2017). The cultivation and environmental impact of mushrooms. New York: Oxford Research Encyclopedia of Environmental Science. http://dx.doi.org/10.1093/acrefore/9780199389414.013.231.

Chen, L., Gong, Y., Cai, Y., Liu, W., Zhou, Y., Xiao, Y., Xu, Z., Liu, Y., Lei, X., Wang, G., Guo, M., Ma, X., \& Bian, Y. (2016). Genome sequence of the edible cultivated mushroom Lentinula edodes (Shiitake) reveals insights into lignocellulose degradation. PLoS One, 11(8), e0160336. http://dx.doi.org/10.1371/journal.pone.0160336. PMid:27500531. 
Chen, S. C., Ge, W., \& Buswell, J. A. (2004). Molecular cloning of a new laccase from the edible straw mushroom Volvariella volvacea: possible involvement in fruit body development. FEMS Microbiology Letters, 230(2), 171-176. http://dx.doi.org/10.1016/S0378-1097(03)00878-4. PMid:14757236.

Chum, W. W., Ng, K. T., Shih, R. S., Au, C. H., \& Kwan, H. S. (2008). Gene expression studies of the dikaryotic mycelium and primordium of Lentinula edodes by serial analysis of gene expression. Mycological Research, 112(Pt 8), 950-964. http://dx.doi.org/10.1016/j. mycres.2008.01.028. PMid:18555678.

Dias, E. S. (2010). Mushroom cultivation in Brazil: challenges and potential for growth. Ciência e Agrotecnologia, 34(4), 795-803. http:// dx.doi.org/10.1590/S1413-70542010000400001.

Ferreira, D. F. (2008). SISVAR: um programa para análises e ensino de estatística. Revista Symposium, 6:36-41.

Gold, M. H., Youngs, H. L., \& Gelpke, M. D. (2000). Manganese peroxidase. Metal Ions in Biological Systems, 37, 559-586. PMid:10693145.

Konska, G. (2006). Lectins of higher fungi (Macromycetes)-their occurrence, physiological role, and biological activity. International Journal of Medicinal Mushrooms, 8(1), 19-30. http://dx.doi.org/10.1615/ IntJMedMushr.v8.i1.20.

Kües, U., \& Liu, Y. (2000). Fruiting body production in basidiomycetes. Applied Microbiology and Biotechnology, 54(2), 141-152. http:// dx.doi.org/10.1007/s002530000396. PMid:10968625.

Kuwahara, M., Glenn, J. K., Morgan, M. A., \& Gold, M. H. (1984). Separation and characterization of two extracellular $\mathrm{H} 2 \mathrm{O} 2$-dependent oxidases from ligninolytic cultures of Phanerochaete chrysosporium. FEBS Letters, 169(2), 247-250. http://dx.doi.org/10.1016/00145793(84)80327-0.

Luz, J. M. R., Nunes, M. D., Paes, S. A., Torres, D. P., Silva, M. C. S., \& Kasuya, M. C. M. (2012). Lignocellulolytic enzyme production of Pleurotus ostreatus growth in agroindustrial wastes. Brazilian Journal of Microbiology, 43(4), 1508-1515. http://dx.doi.org/10.1590/ S1517-83822012000400035. PMid:24031982.

Martínez, A. T. (2002). Molecular biology and structure-functionoflignindegradingheme peroxidases. Enzyme and Microbial Technology, 30(4), 425-444. http://dx.doi.org/10.1016/S0141-0229(01)00521-X.

Menolli, N. Jr., \& Paccola-Meirelles, L. D. (2010). Obtention of Lentinula edodes strains resistant to high temperatures and selection of strains resistant to Trichoderma sp. Ciência e Agrotecnologia, 34, 1640-1646. http://dx.doi.org/10.1590/S1413-70542010000700009.

Nikitina, V. E., Loshchinina, E. A., \& Vetchinkina, E. P. (2017). Lectins from Mycelia of Basidiomycetes. International Journal of Molecular Sciences, 18(7), 1334. http://dx.doi.org/10.3390/ijms18071334. PMid:28640205.

Philippoussis, A. N., Diamantopoulou, P. A., \& Zervakis, G. I. (2003). Correlation of the properties of several lignocellulosic substrates to the crop performance of the shiitake mushroom Lentinula edodes. World Journal of Microbiology \& Biotechnology, 19(6), 551-557. http://dx.doi.org/10.1023/A:1025100731410.

Philippoussis, A., Diamantopoulou, P., \& Israilides, C. (2007). Productivity of agricultural residues used for the cultivation of the medicinal fungus Lentinula edodes. International Biodeterioration \& Biodegradation, 59(3), 216-219. http://dx.doi.org/10.1016/j.ibiod.2006.10.007.
Pomerantz, S. M., \& Murthy, V. V. (1974). Purification and properties of Tyrosinases from Vibrio tyrosinaticus. Archives of Biochemistry and Biophysics, 160(1), 73-82. http://dx.doi.org/10.1016/S00039861(74)80010-X. PMid:4208174.

Royse, D. J., Baars, J., \& Tan, Q. (2017). Current overview of mushroom production in the world. In D. C. Zied (Ed.), Edible and medicinal mushrooms: technology and applications. New York: Wiley. http:// dx.doi.org/10.1002/9781119149446.ch2.

Silva, D. J. (1998). Análise de alimentos: métodos químicos e biológicos (pp. 166). Viçosa: Ed. UFV.

Singh Arora, D., \& Kumar Sharma, R. (2010). Ligninolytic fungal laccases and their biotechnological applications. Applied Biochemistry and Biotechnology, 160(6), 1760-1788. http://dx.doi.org/10.1007/ s12010-009-8676-y. PMid:19513857.

Sousa, M. A. C., Costa, L. M. A. S., Malantrucco, T. C., Pereira, T. S., Bastos, S. C., \& Dias, E. S. (2016). Nutritional and enzymatic potential of the Lentinula edodes strains. International Journal of Current Research, 8, 34557-34561.

Tang, L., Jian, H., Song, C., Bao, D., Shang, X., Wu, D., Tan, Q., \& Zhang, X. (2013). Transcriptome analysis of candidate genes and signaling pathways associated with light-induced brown film formation in Lentinula edodes. Applied Microbiology and Biotechnology, 97(11), 4977-4989. http://dx.doi.org/10.1007/s00253-013-4832-y. PMid:23624682.

Tien, M., \& Kirk, T. K. (1984). Lignin-degrading enzyme from Phanerochaete chrysosporium: purification, characterization, and catalytic properties of a unique $\mathrm{H}_{2} \mathrm{O}_{2}$-requiring oxygenase. Proceedings of the National Academy of Sciences of the United States of America, 81(8), 22802284. http://dx.doi.org/10.1073/pnas.81.8.2280. PMid:16593451.

Tsivileva, O. M., Nikitina, V. E., Garibova, L. V., \& Ignatov, V. V. (2001). Lectin activity of Lentinus edodes. International Microbiology, 4(1), 41-45. http://dx.doi.org/10.1007/s101230100. PMid:11770819.

Tsivileva, O. M., Pankratov, A. N., Nikitina, V. E., \& Garibova, L. V. (2005). Effect of media components on the mycelial film formation in submerged culture of Lentinus edodes (Shiitake). Food Technology and Biotechnology, 43, 227-234.

Vetchinkina, E. P., Gorshkov, V. Y., Ageeva, M. V., Gogolev, Y. V., \& Nikitina, V. E. (2015). Activity and expression of laccase, tyrosinase, glucanase, and chitinase genes during morphogenesis of Lentinus edodes. Mikrobiologiya, 84(1), 78-89. http://dx.doi.org/10.1134/ S0026261715010166. PMid:25916150.

Vetchinkina, E. P., Sokolov, O. I., \& Nikitina, V. E. (2008). Intracellular lectins of Lentinus edodes at various developmental stages of the fungus. Microbiology, 77(4), 496-501. http://dx.doi.org/10.1134/ S0026261708040097. PMid:18825976.

Xu, J. Z., Zhang, J. L., Hu, K. H., \& Zhang, W. G. (2013). The relationship between lignin peroxidase and manganese peroxidase production capacities and cultivation periods of mushrooms. Microbial Biotechnology, 6(3), 241-247. http://dx.doi.org/10.1111/j.17517915.2012.00365.x. PMid:22966760.

Zied, D. C., Maciel, W. P., Marques, S. C., Santos, D. M. S., Rinker, D. L., \& Dias, E. S. (2016). Selection of strains for shiitake production in axenic substrate. World Journal of Microbiology \& Biotechnology, 32(10), 168. http://dx.doi.org/10.1007/s11274-016-2115-3. PMid:27565778. 